\title{
ЖАНРОВО-ІДЕОГРАФІЧНІ ТЕНДЕНЦІЇ У ПОЕТИЦ СУЧАСНОЇ ДИТЯЧОЇ ЛІТЕРАТУРИ
}

\author{
ОЛЬГА НОВОДВОРЧУК \\ Кременчуцький педагогічний коледж імені А.С. Макаренка, Кременчук - Україна \\ novodvorcuk@gmail.com; ORCID: 0000-0002-1225-2470

\section{TRENDY GATUNKOWO-IDEOGRAFICZNE W POETYCE WSPÓŁCZESNEJ LITERATURY DZIECIĘCEJ}

\section{OLHA NOWODWORCZUK}

Kolegium Pedagogiczne w Krzemieńczuku im. Antona Makarenki, Krzemieńczuk - Ukraina

\begin{abstract}
STRESZCZENIE. Artykuł jest próbą zgłębienia cech ukraińskiej poezji dziecięcej początku XXI wieku. Celem badania jest zidentyfikowanie gatunku i cech ideograficznych poezji: innowacyjności i tradycjonalizmu. Śledząc gatunkowe modyfikacje tej poezji, cechy wspólne i wyróżniające, autorka zwraca uwagę na kluczowe elementy poetyki dziecięcej: dyskurs artystyczny i literacki, funkcje poezji, tematykę, strukturę stroficzną wiersza, charakter obrazów, postaci i inne. Udowadnia, że podstawą odnowy gatunków poetyckich są tradycyjne gatunki folkloru i poezji. Autorka ustaliła także, że we współczesnej poezji dla dzieci istnieją organicznie aktualizowane gatunki ludowe (pochwały, straszaki, bajki, nonsensy, wyliczanki, tupot, gry) i nowo powstałe (obrazy-wiersze, sztuczki, kolorowanki, przeszkody, wiersze terapeutyczne). Powstawanie gatunków autorskich spowodowane jest poszukiwaniem nowych form wyrazu osobowości artystów. Modyfikacje gatunkowe poezji dla dzieci są prezentowane jako oryginalne zjawisko w ukraińskiej literaturze początku XXI wieku z szerokim polem do dalszych badań.
\end{abstract}

Słowa kluczowe: literatura dla dzieci, współczesna poezja dla dzieci, modyfikacje gatunkowe, wiersze, „bałamutynki” 


\title{
GENRE-IDEOGRAPHIC TRENDS IN THE POETICS OF CONTEMPORARY LITERATURE FOR CHILDREN
}

\author{
OLHA NOVODVORCHUK
}

Kremenchuk Pedagogical College after A.S. Makarenko

\begin{abstract}
The article attempts to explore the features of early 21 st century Ukrainian poetry for children. The purpose of exploration is to identify the genre and ideographic features of poetry: innovation and traditionalism. Tracing the genre modifications of poetry and their common and distinctive features, the author addresses the key features of poetry for children in general: artistic and literary discourse, the functions of poetry, thematic direction, strophic structure of the poem, the existence of images, characters and others. The article proves that the basis for the renewal of poetic genres is traditional genres of folklore and poetry. There are organically updated folk genres in modern poetry for children (praise, scarecrows, fables, nonsense, counters, patter, games) and newly created genres (poetry-pictures, tricks, coloring books, checks, stumbling blocks, therapeutic poems). The search for new forms of expression of idiosyncrasies of artists leads to the emergence of original genres. These have appeared as an original phenomenon in the Ukrainian literature of the early 21 st century and offer a wide scope for further research.
\end{abstract}

Keywords: children's literature, modern poetry for children, genre modifications, poems, 'balamutynky'

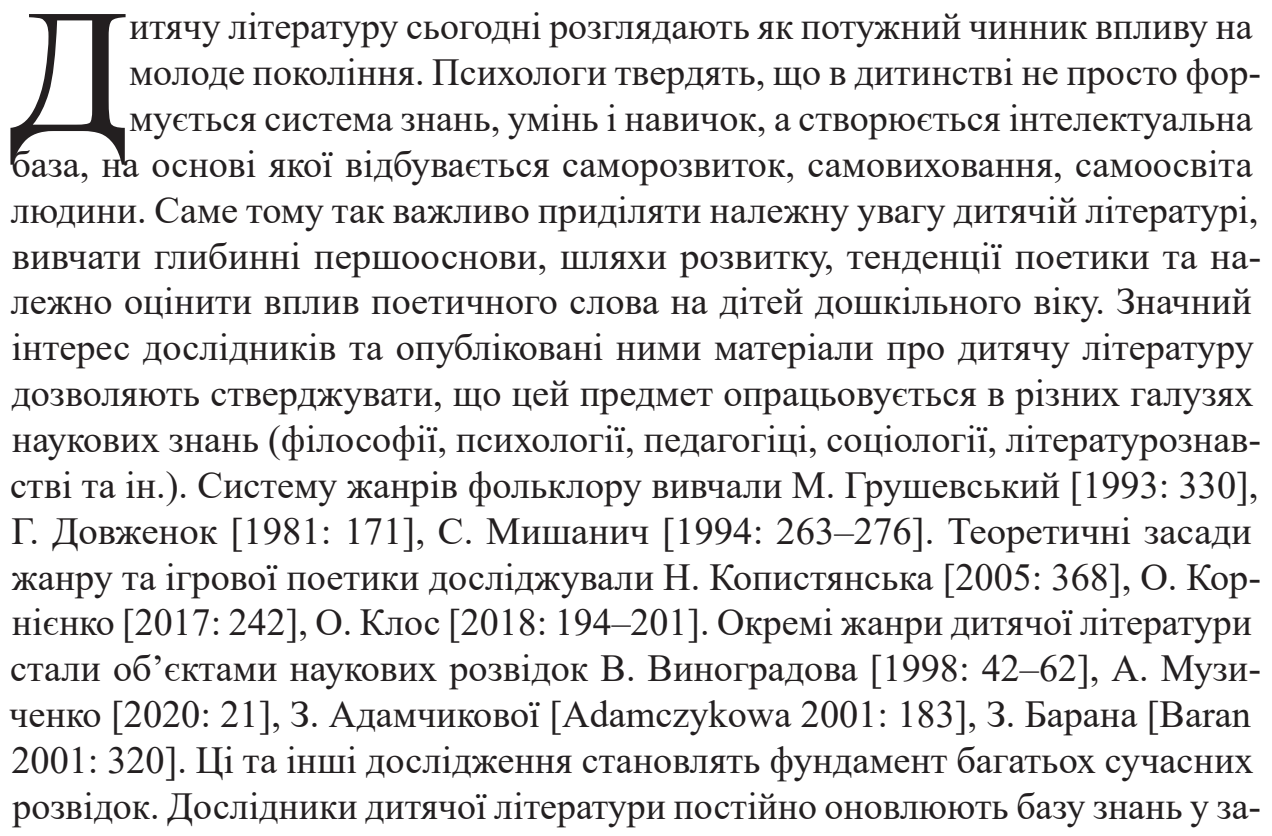


значеній царині науковими працями, які допомагають поглянути на сучасну літературу для дітей по-новому. Зважаючи на генезис і художню своєрідність окремих жанрів, науковці робили спроби систематизувати й типологізувати вірші згідно з тематичним, віковим, композиційним, функціональним принципами. Дослідження поетики віршів для дітей не може вважатися повним без урахування творчих пошуків та новаторських рішень українських письменників у розрізі жанрово-ідеографічних модуляцій початку XXI ст. Цим визначається актуальність нашої розвідки. У межах статті буде запропоновано можливі проєкції дослідження.

Поетичне слово для дітей - виняткове національно-культурне явище, невичерпний ресурс духовного збагачення й становлення. Оскільки реципієнтом такої поезії є дитина, тексти віршів створені за особливими законами архітектоніки. Дитина соціалізується завдяки зразкам громадської поведінки, закладеним у текстовому просторі дитячих поезій. Через культурні цінності, які актуалізуються в дитячих віршах, читач опановує етнокультурний досвід. У XX-XXI століттях українська дитяча література стає простором укорінення та оновлення дитячого фольклору в індивідуальній творчості багатьох авторів. Саме з цього часу професійна дитяча поезія знайшла свій голос, свій репертуар, свої ключові екзистенціальні теми, свою предметну зображальність, свою графіку й ритміку, свою мову, якою говорять уже кілька поколінь дитячих поетів.

Поезія для дітей своїм корінням сягає у найрізноманітніші поетичні зразки фольклору: пісні, забавлянки, дражнилки, небилиці, загадки, лічилки, скоромовки, ігри, казки. Вони запозичені з дитячої народної поезії, яка пройшла довгий шлях, поки вилилася в ті форми, які нам відомі й закріплені в записах: із тих численних пісень і примовок, які чули діти від дорослих, запам'яталося й передавалося з покоління в покоління тільки те, що відповідало органічним запитам дітей. Як стверджує літературознавець Ж. Янковська, „національний характер, ментальність, вдача заховують у собі ті архетипні риси, які проявляються на особистісному та образному рівнях, а пізніше відбиваються у фольклорі, звідки рецептують у літературну творчість" [Янковська 2017: 270-271]. Тож одночасно в дитячій поезії розробляються і фольклорні, й літературні жанри.

Сучасні поети пишуть для дітей, дотримуючись традиційних канонів жанрових форм, змінюючи вміст, оновлюючи дитячу поезію. Таким чином традиційні жанри трансформуються та еволюціонують. У процес оновлення дитячої поезії гармонійно влились сучасні літератори I. Андрусяк, С. Дерманський, О. Мамчич, В. Карп’юк, Ю. Бедрик, О. Горобець, Н. Трохим, М. Савка, Г. Кирпа, І. Калинець, І. Січовик, А. М'ястківський, С. Пантюк, Л. Мовчун, Р. Скиба та ін. Найнеможливіші експерименти і парадокси, радість нових відкриттів, вміння помічати в буденному фантастичне - все це відкривається 
у поезіях сучасних дитячих письменників. Читачів приваблюють як короткі двовірші чи вірші-катрени, так і об'ємні літературні казки у віршах. Важко не помітити, що сучасна поезія для дітей лише подекуди набуває ознак лірики. Дитяча поезія містить переважно не внутрішні переживання поета, а те, що відбувається ззовні, тобто така поезія скерована на об'єкт. Вона має риси епічного твору, містить сюжет і їі можна віднести до певного літературного жанру.

За Літературознавчою енциклопедією „літературний жанр (фр. genre рід, вид) - тип літературного твору, один із головних елементів систематизації літературного матеріалу, класифікує літературні твори за типами їхньої поетичної структури. Ряд літературознавців ототожнює поняття літературний вид і жанр, вживаючи ці слова як синоніми" [Літературознавча енциклопедія 2007, 1: 366-367]. Велика кількість популярних і традиційних жанрів змагається з новими різновидами поетичного мистецтва. Одні жанри поезії швидко витісняють інші, деякі - змішуються, решта розвиваються окремо, не приймаючи змішання стилів. Незважаючи на оновлення жанрів, вони містять традиційні елементи.

Питання жанрового визначення літературного твору - одне 3 найважливіших у сучасному літературознавстві. Ознайомившись із творчістю сучасних письменників, констатуємо, що в сучасній дитячій поезії зберігаються наступні категорії жанрів: 1) за змістовою ознакою; 2) за композиційною ознакою; 3) за сукупністю ознак і особливостей; 4) за метою (розважальна, розвивальна, виховна, повчальна поезія). Панівними групами за змістовою ознакою (тематикою) $є$ пейзажна поезія, календарна поезія, поезія-портрет (героя або антигероя), сюжетна поезія, гумористична поезія, ігрова поезія [Копистянська 2005: 368].

Найпоширенішою в сучасній дитячій літературі України є ігрова поетика, адже вона наближає поезію до дитячого сприйняття світу, створює піднесену, святкову реальність. Ігрова поетика - це художня система, елементи якої мають підвищений ігровий модус і скеровані на гру з читачем. Погоджуємося $з$ думкою О. Корнієнко, яка вважає, що „найактивніше ігрова поетика функціонує на мовному, характерологічному, сюжетно-композиційному і розповідному рівнях твору" [Корниенко 2009]. Для письменника важливою $€$ взаємовідповідність гри, смислового навантаження та оригінальних засобів художнього вираження.

Зважаючи на те, що ментальний простір письменника $є$ основою його літературної творчості, будь-який новий жанр збудовано за законами індивідуального авторського мислення. О. Клос зазначає, що „ігрова модель художнього постмодерністського світу дає можливість віднайти закономірності у творчості письменників-постмодерністів, які проявляються на різних рівнях текстової організації" [Клос 2018: 194]. На думку дослідниці, метою такого тексту є ігрова взаємодія з читачем, якої досягають „завдяки особливим для 
постмодерністичного мистецтва художнім прийомам та засобам, що дає змогу авторам-постмодерністам створити свою особливу поетику гри, що відбивається в особливій ігровій моделі створеного художнього світу" [Клос 2018: 195]. Митець обирає відповідну форму для своїх творів $з$ огляду на ментальну картину світу.

Експерименти зі змістом і формою в площині авторського письма відбуваються постійно. Творчими пошуками займаються поети різних країн. Вони по-сучасному захопливо вибудовують казковий світ дитинства, через який формують найважливіші навички та знання. Польські поети Я. Бжехва, В. Хотомська створювали лінгвістичні поезії або вірші-ребуси [Бжехва 2004]. Російський поет Г. Остер трансформував мовленнєву жанрову форму поради в літературний жанр - шкідливу пораду [Остер 1986]. М. Єсєновський створив своєрідний квазіжанр поезії- бутерброд [Есеновский 2015]. Сучасні українські письменники I. Андрусяк, О. Дерманський, Р. Скиба, Н. Трохим, О. Мамчич, інтегруючи досвід закордонних колег, фольклорні традиції українського народу та власні набутки, демонструють значну оригінальність у модифікації поетичних жанрів.

Збірка С. Дерманського Бигимоти не Медмеді вміщує п’ятнадцять поезій різних жанрів як традиційних, так і новаторських: поезї-ігри, поезї-нісенітниці, поезії-лічилки, поезї-скоромовки, поезї-картинки [Дерманський 2015]. Пустотливі вірші, написані в серйозно-іронічній манері, завдяки грі словом не залишать байдужим читача. У візуально-лінгвістичному вірші Бегемоти не Медмед $i$ автор зосереджує увагу читачів на вживанні лексеми МЕД як окремого слова, так і частини слова (АрхіМЕД, МЕДаль, куМЕДні, діжка-МЕДоїжка, МЕДМЕДі-буркоМЕДі, МЕДяники, МЕДузи, МЕДитують, МЕДпункт та ін.). Така візуальна гра розвиває пам'ять у дітей, збагачує словниковий запас, формує логічне мислення [Дерманський 2015: 34-36].

Деякі спотикачки I. Андрусяка (вкраплення віршів із нетрадиційним ритмом (Хто як засмагав), чи заміна слова, що проситься в риму, на неримоване слово, що не має грайливого змісту (Пірналки) опосередковано сформують у дітей відчуття того, що шлях пізнання світу часом $є$ непростим. Так само, як і сам світ $є$ барвистим і складним, але водночас спільним для всіх “бегемотів” і “жираф”.

Баламутинки, кольоровинки, перевіршики створив для дітей Р. Скиба. Автор назвав баламутинками свої “абсурдні” вірші, які за змістом нагадують англійські лімерики: Хто гариює по степах? / Стадо диких черепах! / Не догнати, не впіймати... / Прудконогі -просто страх! (Бадьора черепаша баламутинка) [Скиба 2010]; Білий зайчик білим вушком / притулився до подушки - / Хай собі дріма... / Білосніжна завірюха / у вікно замерзле дмуха, / Бо ж таки зима... (Затишний віршик) [Скиба 2017]. У перевіршиках Р. Скиба створив переспіви найкращих зразків “дитячої класики”, перекладених і адап- 
тованих для українських дітей. Порівняйте: Уронили мишку на пол, / Оторвали мишке лапу. / Все равно его не брошу - / Потому что он хороший (Мишка) [Барто 1999]; у ведмедика мого Михася / Дуже скрушною доля вдалася. / Хтось відсмикнув Михасеві лапу, / Зафутболив його під канапу... / Все-одно бідолаху не кину, / Бо ведмедик мій - також людина! (Михась) [Скиба 2017].

Знавці сучасної літератури А. Люксембург та Г. Рахімкулова виділяють такі властивості, характерні для ігрових текстів: оманливість фабули, ігрова структура тексту, амбівалентність, ігрова нарація, інтертекстуальність, театралізація дії, лабіринтизм, калейдоскопічність, невірогідність оповіді, присутність автора у тексті, ігрова стилістика тексту [Люксембург, Рахімкулова 2006]. Серед ігрових прийомів сучасні поети найчастіше використовують оказіоналізми-інновації, які не зафіксовані в загальному використанні й створюються в процесі мовленнєвої діяльності дитини. У Н. Трохим подибуємо вихвалянку: у нашому місті / всі стріхи - ребристі, / всі замки - шпилясті, / будинки кутасті, / тітки - вихилясті, / дядьки - вихвалясті, / садочки - квітчасті, / вікония - тратчасті. / а щоб не боятись / містянам напасті - / у місті на варті / вор-р-рони-горласті! (Вихвалянка) [Трохим 2015: 3]. Мимоволі читач стає учасником захопливої лексичної гри, до якої так хитро залучає авторка.

Погоджуємося з думкою дослідниці письменницького ідіостилю І. Бабій, яка зазначає: „Лексичні інновації художнього тексту - важливий естетичний компонент авторської картини світу письменника. Індивідуально-авторська словотворчість $€$ джерелом збагачення письменницької мови” [Бабій 2015: 11]. Подібні експерименти свідчать про самобутність та мистецьку оригінальність ідіостилю письменника. Крім того, пошуки митця у царині словотворення сприяють актуалізації лейтмотивного образу твору, забезпечують формальну й змістову новизну тексту.

Незвичайний світ небилиці викликає сміх перевернутою реальністю: Страус річкою пливе. / Крокодил в дуплі живе. / Кенгуру город садовить. / а жирафа рибу ловить... (Страус річкою пливе) [Малик 1984: 6]. Так само зранку звичайний ослик має звичайний сніданок - ciм пориій сnагетi, $n$ 'ять літрів сметани, борщу так відерие, товчеників з перием... (Казка про ослика) [Крук 2018: 14]. Алогізми та словесна тканина твору формують абсурдність нісенітниць.

На початку XXI століття в дитячій літературі набув популярності ще один поетичний жанр - страшилка. Погоджуємося з думкою Я. Сазонової, яка стверджує, що „...фікціональний дискурс жахів $є$ прикладом регулярного моделювання страху мовними засобами" [Сазонова 2013: 185]. Якщо раніше страшилка побутувала в дитячому фольклорі лише в прозовій формі, то сьогодні з'явилися вірші-страшилки: у темному-темному лісі / жив темний-претемний ліс, / а в темнім-претемнім лісі / було дуже темно скрізь. / Там бігали темні вовчиська / $і$ темних ловили зайців, / i там, не далеко й не 
близько, / жив дідько у чорнім яйщі... (Страшна казка) [Андрусяк 2018]. Художні особливості страшилки залишаються незмінними: використання сталої композиції (зачин, основна частина, кінцівка), ланцюжкове розгортання подій, вживання прикметників на позначення чорного кольору та його відтінків, похмурий колорит, несподіване закінчення тощо.

Останнім часом поезія для дітей набуває ще й практичного характеру. Перебуваючи в постійній близькості з проблемами наймолодших читачів, письменники створюють вірші, які б допомагали дітям подолати труднощі, пов'язані з фізичним чи психічним здоров'ям дитини. 3'являються тераneвтичні вірші, покликані допомогти подолати дитині труднощі з власними страхами, гіперактивністю, неуважністю, дефектами мовлення чи координації рухів. Про темряву й тіні на стінах вірш Ручні п'ятиніжки Г. Крук: у Надійки на стіні, / біля ліжка, / поселилися смішні / П'ятиніжки: / раз, два, три, чотири, n'ять - / із якої починать? [Крук 2018: 16]. Дещо несподівана, але тим і цікава Колискова Л. Мовчун зі збірки Усе підростає. Тут є й трішки остраху, й домашній затишок, і гарний художній образ: Клащнув замок, / відчинилися двері. / Вечір приїхав / на чорній пантері. / Я не боюсь: / ия пантера не хижа. / Ось вона місяиь, / мов блюдечко, лиже [Мовчун 2010: 44]. Терапевтичні вірші здатні розв'язувати проблеми дітей, допомагають знайти їм сили у собі, повірити в успіх.

Читання терапевтичних віршів може супроводжуватися грою. Наприклад, разом із дитиною можна повправлятись у створенні тіней. Елізабет Козен Лоу (Elizabeth Cothen Low) - авторка Big Book of Animal Rhymes, Fingerplays, and Songs, пропонує такі вірші відносити до категорії рuми-діï / Action rhyme (віршовані твори, де рими можуть супроводжуватися рухами рук і тіла) [Elizabeth Cothen Low 2011: 156]. Вірш Г. Крук слугуватиме дитині вправою для подолання труднощів із вимовою певних звуків: в Марти з мороком морока - / темно, лиш примружить око, / страшно, лиш примружить око ... / Марта в морок - ні півкроку! [Крук 2018: 20]. Авторка дуже вдало використала омоніми “мОрок” i “морОка", а також “погралася" з іншими -оками (око, сорока, збоку, півкроку), таким чином вірш став придатним для застосовування в логопедичних іграх і формуванні чіткої вимови.

Сучасні автори продовжили традиції поетів минулого століття та написали чимало віршованих казок для дітей (Г. Крук Казка про мишу, Казка про ослика, Г. Осадко Як дракончик Юрасик врятував ліс від браконьєра, М. Савка Казка про старого Лева тощо). Традиційними жанровими ознаками жанру віршованої казки $\epsilon$ антропоморфізм, велика кількість другорядних персонажів, перелічувальна інтонація, повчальний зміст. Жанр літературної казки, його різновиди та модифікації мають потужний генологічний потенціал.

Складні етапи розвитку української літератури, віршування й інші фактори вплинули на формування жанру авторської віршованої казки. Ідучи 
в ногу з часом, жанр віршованої казки постійно зазнає нових трансформацій, збагачується сучасними реаліями, розкриває проблеми сьогодення. 3 доби становлення нової української літератури змінилася не тільки тематика казок, а й віршування, художні образи: ...Потім наш ослик збирався до школи. / Зайвого в сумку не клав він ніколи, / хіба щзо: машинку, бінокля, меча, свисток, / пістолет, щуо „в десятку” влуча, / для класних забав надувного м'яча, / маленьке біленьке пухнасте зайча... / а зошит не влазив, ну як не крути!.. / Як бачите, зайвого тут не знайти... (Казка про ослика) [Крук 2018: 18]. Хоча вірш починається традиційним для казки зачином Жив-собі, був-собі ..., авторка пристосовує іiі до реалій сьогодення, осучаснює (ослик їсть спагеті, цукерки, п’є морквяний сік, бавиться біноклем, пістолетом та надувним м'ячем).

Подібну трансформацію спостерігаємо в казці М. Савки Казки Старого Лева. У цьому творі гривастий персонаж Старий Лев отримав детальну біографію: ...У Відні колись він отримав освіму, / За час изарювання об ’̈здив півсвіту, / у Греції, Швеиії жив, у Бомбеї, / Бував у Венеції, бачив Париж, / Останнє кохання зустрів на Бродвеї- / Чимало побачив наш Лев дивовиж... [Савка 2018: 76]. Старий Лев запрошує заморських друзів Жирафу, Крокодила й Слона, щоб вони допомогли йому поремонтувати дах мансарди, який протік після дощу. Пригоди, які трапляються з персонажами казки, кумедні й водночас дивовижні: Слон застряг у брамі, фургон із Крокодилом ледь не наїхав на Слона, Жирафа гойдає дітей на шиї, Лев випав із вікна. Авторка змальовує представників різних професій (мера, кельнера, стюардесу, інспектора, пожежників, репортерів) та найрізноманітніший транспорт (літак, підводний човен, трамвай, фургон) поєднуючи таким чином фантазію і реальність, минуле і сучасне.

Результати дослідження дають підстави стверджувати, що в сучасній українській літературі для дітей переважають малі та середні за обсягом жанрові форми; прослідковується тенденція до синтезу та модифікацій існуючих жанрів.

Отже, дитяча поезія початку XXI століття демонструє у своєму розвої значущі й закономірні тенденції, які випливають із попереднього етапу іiі становлення й обумовлені впливом суспільно-історичної еволюції в сьогочасному суспільстві. У поетичних творах для дітей спостерігається тенденція до скорочення художнього тексту, його стиснення. Вивчення українськими сучасними поетами фольклорного розмаїття та досвіду світової класики поезії для дітей зближує художні світи, закладає основи нової традиції, формує перспективу жанру. в українській дитячій літературі сьогодення поетичні новації виражені в оновленні стилів, дискурсів, використанні сучасних образів, ігрових прийомів. Долаються поетичні канони, але при цьому не рветься зв'язок із традицією. Як наслідок, у дитячій літературі побутують оновлені фольклорні жанри: віршовані казки, вихвалянки, лічилки, небилиці, нісенітниці, скоромовки, поезї-ігри, страшилки. Також ми зафіксували самобутні жан- 
ри: баламутинки, кольоровинки, перевіршики, поезї-картинки, спотикачки, терапевтичні вірмі (рими-діi). Їхній ідеографічний простір насичений не лише фантасмагоріями, але й реальними картинами життя. Ці твори увібрали в себе специфічні, притаманні сьогоденню риси. Переконуємося, що усталені традиційні форми поступово видозмінюються, утворюючи якісно нове явище в жанрово-ідеографічному просторі дитячої літератури.

\section{Список використаної літератури}

Бабій І., Художньо-зображальна роль авторських неологізмів у формуванні письменницького ідіостилю, [в:] „Studia Ukrainica Posnaniensia”, 2015, z. 3, с. 11-18.

Виноградов Г.С., Детская сатирическая лирика, [в:] „Камены”, 1998, № 1-2, с. 42-62.

Грушевський М., Казка (Нама казкова традииія. Головніші казкові мотиви. Інтернаиіональне і національне), [в:] Історія української літератури: в 9 кн., за ред. В. Дончика, т. 1, Київ: Либідь, 1993.

Довженок Г., Украӥнський дитячий фольклор: віршовані жанри, Київ: Наук. думка, 1981. Игровая поэтика: сб. науч. тр. рост. шк. игровой поэтики, под ред. А.М. Люксембурга, Г.Ф. Рахимкуловой, Ростов-на-Дону: Литфонд, Вып. 1, 2006.

Клос О., Ігрова модель художнього світу у візії постмодернізму, [в:] „Вісник Львівського університету. Серія філологічна", 2018. вип. 67, ч. 2, с. 194-201.

Ковалів Ю.І., Жанрова типологія, [в:] „Літературознавча енциклопедія”: у 2 т., Київ: ВЦ „Академія”, 2007, т. 1: А-Л, с. 366-367.

Копистянська Н.Х., Жанр, жанрова система у просторі літературознавства [монографія], Львів: ПАІС, 2005.

Корниенко О.А., Типология форм игровой поэтики в литературе, [в:] Электронный pecypc: http://dspace.nbuv.gov.ua/bitstream/handle/123456789/16594/51-Kornienko. pdf?sequence $=1(21.11 .2020)$.

Корнієнко О.О., Ігрова поетика у літературі: навч. посібник, Київ: Видавництво НПУ ім. М.П. Драгоманова, 2017.

Мишанич С.В., Система жанрів в українському фольклорі, [в:] „Українознавство: Посібник”, за ред. П. Кононенка, Київ: Зодіак-ЕКО, 1994, с. 263-276.

Музиченко А., Жартівливі віршики для гри, [в:] Електронний ресурс: http://www.barabooka. com.ua/zhartivlivi-virshiki-dlja-gri/ (16.09.2020).

Сазонова Я., Одоративне підгрунтя моделювання емоиій тривоги і страху у фікиіональному дискурсі жахів, [в:] „Studia Ukrainica Posnaniensia”, 2013, z. 1, с. 185-193.

Янковська Ж., Парадигма фольклорно-літературної архетипності, [в:] „Studia Ukrainica Posnaniensia", 2017, z. 5, c. 269-277.

Adamczykowa Z., Literatura dla dzieci. Funkcje - kategorie - gatunki, Warszawa: Wyższa Szkoła Pedagogiczna TWP, 2001.

Baran Z., W kręgu poezji religijnej dla dzieci, Kraków: Wydawnictwo Naukowe Akademii Pedagogicznej, 2001. 


\section{Spysok vykorystanoi literatury [References]}

Babii I., Khudozhno-zobrazhalna rol avtorskykh neolohizmiv u formuvanni pysmennytskoho idiostyliu [Artistic and Pictorial Role of Author's Neologisms in the Formation of Literary Idiosyncrasy], [v:] „Studia Ukrainica Posnaniensia”, 2015, z. 3, s. 11-18.

Vinogradov G.S., Detskaya satiricheskaya lirika [Children's Satirical Lyrics], [v:] „Kameny”, 1998, № 1-2, s. 42-62.

Hrushevskyi M., Kazka (Nasha kazkova tradytsiia. Holovnishi kazkovi motyvy. Internatsionalne $i$ natsionalne) [Fairy Tale (Our Fairy-Tale Tradition. The Main Fairy-Tale Motives. International and National)], [v:] „Istoriia ukrainskoi literatury”: v 9 kn., за ред. В. Дончика, t. 1, Kyiv: Lybid, 1993, s. 330.

Dovzhenok H., Ukrainskyi dytiachyi folklor: virshovani zhanry [Ukrainian Children's Folklore: Poetic Genres], Kyiv: Nauk. dumka, 1981.

Igrovaya poe'tika [Game Poetics]: Sb. nauch. tr. rost. shk. igrovoj poe'tiki, pod red. A.M. Lyuksemburga, G.F. Raximkulovoj, Rostov-na-Donu: Litfond, Vyp. 1, 2006.

Klos O., Ihrova model khudozhnoho svitu u vizii postmodernizmu [Game Model of the Art World in the Vision of Postmodernism], [v:] „Visnyk Lvivskoho universytetu. Seriia filolohichna”, 2018, vyp. 67, ch. 2, s. 194-201.

Kovaliv Yu.I., Zhanrova typolohiia [Genre Typology], [v:] „Literaturoznavcha entsyklopediia”: u 2 t., Kyiv: VTs „Akademiia”, 2007, t. 1: A-L, s. 366-367.

Kopystianska N.Kh., Zhanr, zhanrova systema u prostori literaturoznavstva [Genre, Genre System in the Space of Literary Criticism] [monohrafiia], Lviv: PAIS, 2005.

Kornienko O.A., Tipologiya form igrovoj poe'tiki v literature [Typology of Forms of Play Poetics in Literature], [v:] Elektronnyi resurs: http://dspace.nbuv.gov.ua/bitstream/ handle/123456789/16594/51-Kornienko.pdf?sequence=1 (21.11.2020).

Korniienko O.O., Ihrova poetyka u literaturi [Game Poetics in Literature]: navch. posibnyk, Kyiv: Vyd-vo NPU im. M.P. Drahomanova, 2017.

Myshanych S.V., Systema zhanriv v ukrainskomu folklori [The System of Genres in Ukrainian Folklore], [v:] „Ukrainoznavstvo: Posibnyk”, за ред. П. Кононенка, Kyiv: Zodiak-EKO, 1994, s. 263-276.

Muzychenko A., Zhartivlyvi virshyky dlia hry [Humorous Poems for the Game], [v:] Elektronnyi resurs: http://www.barabooka.com.ua/zhartivlivi-virshiki-dlja-gri/ (16.09.2020).

Sazonova Ya., Odoratyvne pidgruntia modeliuvannia emotsii tryvohy i strakhu u fiktsionalnomu dyskursi zhakhiv [Odorative Basis for Modeling the Emotions of Anxiety and Fear in the Fictional Discourse of Horror], [v:] „Studia Ukrainica Posnaniensia”, 2013, z. 1, s. 185.

Iankovska Zh., Paradyhma folklorno-literaturnoi arkhetypnosti [Paradigm of Folklore and Literary Archetype], „Studia Ukrainica Posnaniensia”, 2017, z. 5, s. 269-277.

Adamczykowa Z., Literatura dla dzieci. Funkcje - kategorie - gatunki [Children's Literature. Functions - Categories - Genres], Warszawa: Wyższa Szkoła Pedagogiczna TWP, 2001.

Baran Z., W kręgu poezji religijnej dla dzieci [In the Circle of Religious Poetry for Children], Kraków: Wydawnictwo Naukowe Akademii Pedagogicznej, 2001. 


\section{Список використаних джерел}

Андрусяк І., Лякаиія, Київ: Фонтан казок, 2017.

Андрусяк I., Страшна казка, [в:] Електронний ресурс: https://www.ukrlib.com.ua/books/ printit.php?tid=16142 (15.10.2019).

Андрусяк I., Твори для дітей. Мала Сторінка, [в:] Електронний ресурс: https://mala.storinka. org/\%D0\%B4\%D0\%B8\%D1\%82\%D1\%8F\%D1\%87\%D1\%96-\%D0\%B4\%D1\%80\%D0\% B0\%D0\%B6\%D0\%BD\%D0\%B8\%D0\%BB\%D0\%BA\%D0\%B8.html (15.10.2019).

Барто А., Избранные стихи, Москва: Планета детства: Премьера, 1999.

Бжехва Я., На землях Бергамотах, Львів: Видавництво Старого Лева, 2004.

Дерманський С., Бигимоти не медмеді, Київ: Фонтан казок, 2015.

Есеновский М., Небо в помидорах, Стихи. Журнал поэзии „Плавучий мост”, 2015, № 4 (8), [в:] Электронный pecypc: http://www.plavmost.org/?p=6440 (12.10.2021).

Крук Г., Раз овечка, два овечка, Харків: Видавництво Vivat, 2018.

Малик Г., Страус річкою пливе, Київ: Веселка, 1984.

Мовчун Л., Усе підростає, Київ: Грані - Т, 2010.

Осадко Г., Як дракончик Юрасик врятував ліс від браконьєра, [в:] Електронний ресурс: http://abetka.ukrlife.org/kazki.html (14.08.2020).

Остер Г., Вредные советы: книга для непослушных детей и их родителей, Москва: Московский книжный двор, 1990.

Савка М., Казка про старого Лева, Львів: Видавництво Старого Лева, 2011.

Скиба Р., Баламутинки, Львів: Видавництво Старого Лева, 2011.

Скиба Р., Затишний віршик, [в:] „Маленька фея”, 2011, № 2, с. 15.

Скиба Р., Перевіриики, Тернопіль: Навчальна книга - Богдан, 2010.

Трохим Н., Львівські віршики, Львів: Джезва, 2015.

Хотомская В., Стоножка, Ленинград: Издательство „Детская литература”, 1982.

Big Books of Sesons, Holidays, and Weather [compiled by E. Cothen Low], Westport: Libraries Unlimited, 2011.

\section{Spysok vykorystanykh dzherel [References]}

Andrusiak I., Liakatsiia [Lakatsiya], Kyiv: Fontan kazok, 2017.

Andrusiak I., Strashna kazka [A Terrible Tale], [v:] Elektronnyi resurs: https://www.ukrlib.com. ua/books/printit.php?tid=16142 (15.10.2019).

AndrusiakI.,Tvorydliaditei.MalaStorinka[WorksforChildren.SmallPage],[v:]Elektronnyiresurs: https://mala.storinka.org/\%D0\%B4\%D0\%B8\%D1\%82\%D1\%8F\%D1\%87\%D1\%96-\% D0\%B4\%D1\%80\%D0\%B0\%D0\%B6\%D0\%BD\%D0\%B8\%D0\%BB\%D0\%BA\%D0\%B8. html (15.10.2019).

Barto A., Izbrannye stixi [Selected Poems], Moskva: Planeta detstva: Prem'era, 1999. 
Bzhexva Yan., Na zemlyax Bergamotax [In the Lands of Bergamot], L'viv: Vidavnictvo Starogo Leva, 2004, s. 32.

Dermanskyi S., Byhymoty ne medmedi [Bigimots are not Bears], Kyiv : Fontan kazok, 2015.

Esenovskij M., Nebo v pomidorax [Tomato Sky], Stixi. Zhurnal poe’zii „Plavuchij most”, № 4

(8), 2015, [v:]: http://www.plavmost.org/?p=6440 (12.10.2021).

Kruk H., Raz ovechka, dva ovechka [One Sheep, two Sheep], Kharkiv: Vydavnytstvo Vivat, 2018.

Malyk H., Straus richkoiu plyve [An Ostrich Swims Along the River], Kyiv: „Veselka”, 1984.

Movchun L., Use pidrostaie [Everything is growing], Kyiv: Hrani-T, 2010.

Osadko H., Yak drakonchyk Yurasyk vriatuvav lis vid brakoniera [Like a Dragon, Jurassic

Saved the Forest From a Poacher], [v:] Elektronnyi resurs: http://abetka.ukrlife.org/kazki. html (14.08.2020).

Oster G., Vrednye sovety: kniga dlya neposlushnyx detej i ix roditelej [Bad Advice: a Book for Naughty Kids and their Parents], Moskva: Moskovskij knizhnyj dvor, 1990.

Savka M., Kazka pro staroho Leva [A Tale about an Old Lion], Lviv: Vydavnytstvo Staroho

Leva, 2011.

Skyba R., Balamutynky [Balamutynky], Lviv: Vydavnytstvo Staroho Leva, 2011.

Skyba R., Zatyshnyi virshyk [A Cozy Poem], [v:] „Malenka feia”, 2011, № 2, s. 15.

Skyba R., Perevirshyky [Perevershiki], Ternopil: Navchalna knyha - Bohdan, 2010.

Trokhym N., Lvivski virshyky [Lviv Poems], Lviv: Dzhezva, 2015.

Xotomskaya V., Stonozhka [Stonogka], Leningrad: Izdatel'stvo: Detskaya literatura, 1982.

Big Books of Sesons, Holidays, and Weather [compiled by E. Cothen Low], Westport: Libraries Unlimited, 2011. 